\title{
Young People's Opinions on Rural Sweden
}

\author{
Lena Boström ${ }^{1} \&$ Rolf Dahlin ${ }^{2}$ \\ ${ }^{1}$ Department of Education, Mid Sweden University, Sundsvall, Sweden \\ ${ }^{2}$ Department of Computer and Systems Sciences. Mid Sweden University, Sundsvall, Sweden \\ Correspondence: Lena Boström, Department of Education, Mid Sweden University, Sidsjövägen 5, 85170 \\ Sundsvall, Sweden. Tel: 46-10-142-8263. E-mail: lena.bostrom@miun.se
}

Received: November 14, 2017

doi:10.5539/ies.v11n6p45
Accepted: March 1, $2018 \quad$ Online Published: May 29, 2018

URL: https://doi.org/10.5539/ies.v11n6p45

\begin{abstract}
This study focus on adolescents motivations about remaining in rural areas in the Mid Sweden Region, a part of Sweden with decreasing school performance scores and high out-migration. The study is based on 1,500 young people's responses to a Web-based survey within the framework of a regional school development project. The research questions focused on: whether youths were going to stay there or move the future in urban or rural areas, influences, and the future choices and differences among genders, regions, and age groups. The empirical data are processed with statistical analysis. The study confirms previous research on young people's relocations from rural areas; jobs and education are important motives, and the most prone to move are women. What is new knowledge is that lessons about the region's importance have a positive, significant effect on individuals' plans to remain in their home municipality. This can and should be highlighted in local, regional, and national politics, but more importantly in school discourses. Since school plays a role in students' thinking and future choices, a larger formation effort could be of great value for norms and regional political standpoints. The study has relevance to the international terms of similar geographical areas.
\end{abstract}

Keywords: regional development, regional youth voices, school improvement

\section{Introduction}

Students in the Mid Sweden Region (Note 1) are performing increasingly worse with regard to merit ratings and attainments. The national school results in some parts of the region have steadily decreased over the past nine years (Skolverket, 2014). The level of education is also lower compared to other parts of the country. Far too few students at the region's university come from and/or remain in the region, and a relatively high proportion of well-educated individuals move away from the region (Statistiska Centralbyrån, 2014). Because of these reasons, representatives from private and public sectors in the region as well as researchers at Mid Sweden University began a three-year research project, The Best Regional Educations System in the World (V-brus), in autumn 2012. Its purpose was to develop the region by improving the situation for students, develop practical school activities and leadership in school, and research the changes and development. This study focuses on adolescents opinions and is based on about 1,500 responses from a Web-based survey. It is about young people's opinions about the sparsely populated/rural areas (Note 2), the future, influencing factors, and the role of the school.

First, a background on the rural areas and youth migration is given, followed by previous research on youth themes in rural areas, as well as research on the region's young people. Then, research on urban/rural norms and class, gender, and participation in the regional perspective is described. After that, the study's methodological starting point is recognized, and finally the results of the study with analyses and implications for youth in rural areas are presented.

\section{Background and Previous Research}

This section includes background on youth migration from rural/sparsely populated areas, previous research on regional development and school improvement, and specific research on my region's young people.

\subsection{Rural Areas, Sparsely Populated Areas, and Youth Migration}

To define rural and sparsely populated areas is not easy (Westholm, 2008). The Growth Board (Tillväxtverket, 2014) believes that rural areas cover regions outside of metropolitan areas, which cover $1 / 5$ of the population. The Board of Agriculture (Jordbruksverket, 2013) defines four different types of regions based on population density 
and commuting patterns, namely metropolitan areas, urban areas, rural areas, and sparsely populated rural areas. According to estimations from The Board of Agriculture, $34 \%$ of the population in Sweden lives in rural areas. For years, a large majority of Swedish municipalities - 250 of 290 - lose their young people, resulting in a declining population (Jordbruksverket, 2013). This trend of young adults and particularly young women move from rural areas exists and will continue to do so (Boverket, 2012). Population reduction and demographic changes mean that local governments lose tax and market base, which in turn affects employment and enterprise development (settlement) and ultimately welfare (Myndigheten för tillväxtpolitiska utvärderingar och analyser, 2011; Möller, 2011; Svensson, 2006b; 2014; Westholm \& Waldenström, 2008).

Research on rural areas is multidisciplinary, with emphasis on social sciences, but with ramifications for the humanities and sciences. Rural research is broad and difficult to define. The area spans a variety of areas in society, such as entrepreneurship, infrastructure, and gender. A recurring issue in regional and national policy research is how the northern part of Sweden, which consists of sparsely populated areas, will be able to survive over the long term (e.g., Westholm \& Waldenström, 2008; Nilsson \& Lundgren, 2015). In this context, even the young people and education play an important role (Rönnblom, 2014; Vallström \& Vallström, 2014).

\section{Previous Research on Youth and Regional Development}

There is a lack of research on young people in rural areas, according to Svensson (2006a), who claims that it is not possible to separate youths from the regional political and demographic problems. Helve pointed out in 2003 that, when sparsely populated areas are studied, the focus is outside the rural perspective and that, when young people are studied, the focus is outside the rural perspective. Helve also noted that the research field throughout the Nordic countries is relatively small. The knowledge field young and regional development thus needs to be clarified (Möller, 2011). In a survey about rural youth in Nordic countries published in 2003 (Helve, ed.), it was found that it is mostly young women who move away from the periphery to urban areas for work or study. The same applies to research on regional development and school improvement, both nationally and internationally (Boström, 2015 $\mathrm{a}, \mathrm{b})$. Overall, it can be stated that there is a gap in the knowledge about rural youth and the school perspective.

As for university education, the young people who are most affected have finished upper high school programs and have a family with educational aspiration. In percentage terms, there are fewer young people from rural areas who continue with higher education compared to youths living in big cities. The difference may be due to sparsely populated areas' socio-structural position, their inhabitants, and their cultural tradition (Hammarström, 2004). However, classic reproductive variables like language and cultural capital are mentioned very often as being important in the public document for regional development (Florida, Mellander, \& Stolarick, 2010). There are large regional differences in the proportion of young people who begin university studies. The largest proportion of young university students is found in the metropolitan counties of Stockholm, Uppsala, and Skåne, while Jämtland, Gotland, and Norrbotten have the lowest transition frequency. Västernorrlands County is in the middle (UKÄ, 2014).

\subsection{What Do We Know about the Young People in the Mid Sweden Region?}

For municipalities, there are simple ways to find out how the situation with young people looks locally, such as a national survey that assesses youths (LUPP) that has been implemented since 2003. The survey was developed and administered by the Youth Board in order to develop an effective youth policy. The purpose of LUPP is to find out how young people's situation looks locally in order to develop an effective youth policy based on cooperation between different sectors (www2.mucf.se). In the past, LUPP questionnaires for the Mid Sweden region (Kostela, Jansson, \& Moller, 2013; Dalin, Bostedt, \& Blusi, 2013) focused on high school students and revealed that many young people believed that they would move from the home municipality. More young women than young men believed that they would move, in terms of both Mid Sweden Region and the whole country. The latter category includes results from 50 municipalities that participated in the data collection in 2012, in which the three largest cities were not represented. The corresponding proportions for young men were $55 \%, 56 \%$, and $57 \%$. The Mid Sweden counties did not differ much from other counties with small- and medium-sized municipalities (diagram $1)$. 


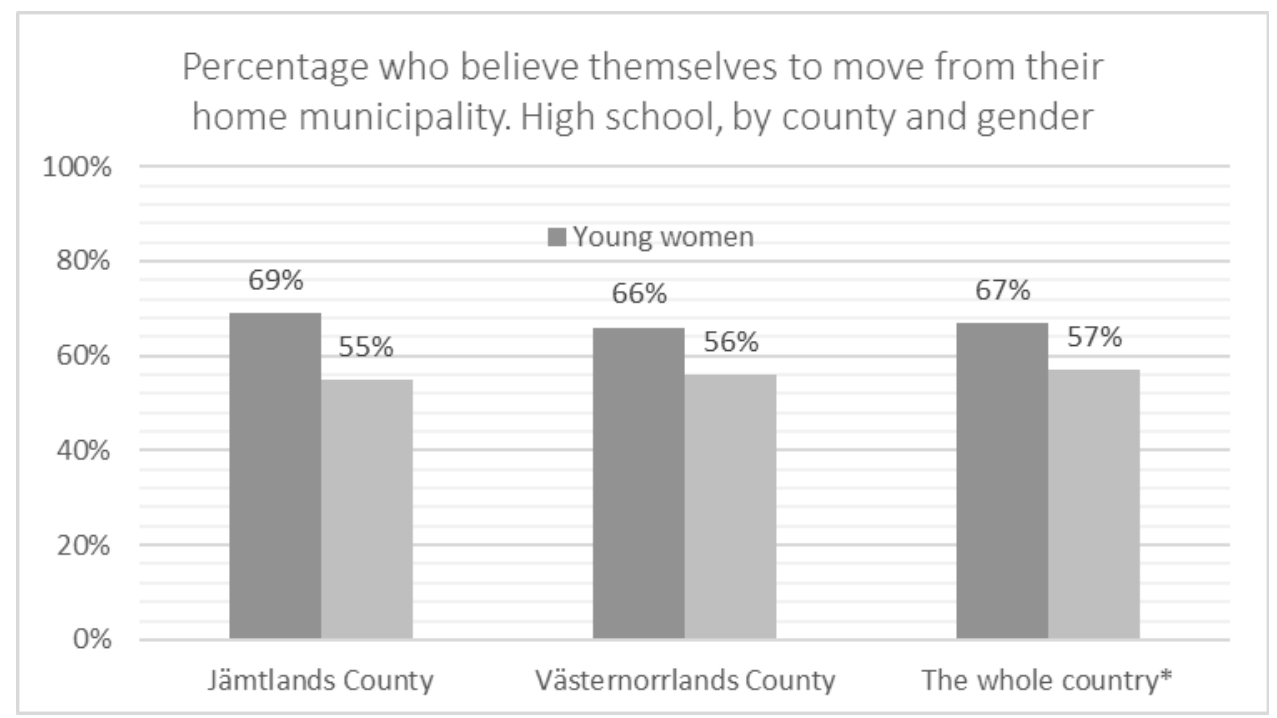

Figure 1. Moving after high school—Jämtlands and Västernorrlands counties and the national average

The decision to move is often complex, according to the LUPP, but the three most popular reasons for moving were education, jobs, and "to try something new." One difference between the genders is that young women feel that there is less to do in the region, compared with young men, and the opportunity to try something new makes them want to move.

When it comes to reasons to consider moving back to the region, $60 \%$ of young women and $38 \%$ of young men say that genealogy and family entice them to move back, and with regard to jobs, $31 \%$ of young men and $18 \%$ of young women answered that this may be a contributing factor. Dalin et al. (2013) noted that "the more relationships with friends and family in a municipality as a re-immigrant person has, the greater are the chance that the person establishes itself there" (p. 83). This is a result that recurs in the LUPP surveys, which are given in the rural/sparsely populated counties. Many of the activities available are often focused on sports and outdoor activities, which by tradition is perhaps sufficient for many young men. However, young women require other things as well to be happy. Compared with LUPP responses in the whole nation, both young women and young men in the Mid Sweden region are slightly more dissatisfied with the leisure offered. Approximately $48 \%$ of young women and $46 \%$ of young men are members of an association (which is slightly lower than the national average). When it comes to leisure, young men believe that there is a little more to do in their leisure time, compared to what young women think (Dalin et al., 2013; Kostela et al., 2013).

Other key findings from Västernorrlands County include that the number of high school students who are willing to start their own business in the future was quite high, at $45-63 \%$. Furthermore, students believed that teaching and teachers' importance for the assessment of the education situation was important. Student responses indicated that school is an issue that should be prioritized by the municipality (Dalin et al., 2013). In terms of higher educated people in the Mid Sweden region, it is lower than in the whole country. Regarding the transition to higher education, it is lower in this region than anywhere else in the whole country. Specifically, Jämtland has low higher education transition frequency. Urban municipalities have higher transition frequency than rural municipalities (UKÄ, 2014). Furthermore, parents' educational level has importance in the transition to higher education. Freshmen from the region study to a lesser extent at Mid Sweden University, compared with a few years ago. At the beginning of the 2000s, half of the freshmen at Mid Sweden University came from the region. That share has decreased to about one-third of freshmen. Freshmen from Jämtland are more "Mid-Sweden-university-loyal" than freshmen from Västernorrland (Lindh, 2015).

\section{Urban and Rural Norms}

This section focuses on norms concerning moving or staying in rural areas, as well as gender, class, and participation.

\subsection{To Move or Stay?}

The young people's choices about moving or staying in rural areas are related and measured against the collective values and norms (Kåks, 2007). Moving to a big city is associated with feeling successful, for young people, adults, and rulers. The opposite notion is to continue living in the countryside or in small cities, which is seen by 
many as a passive act or as, "remaining there." The urban norm includes a set of assumptions, which says that life in the city is natural and attractive. This does not need to be explained or defended. In previous research, the norm formation for city and rural areas is described as an underlying grid for migration from rural areas. Urbanity of interpretation seems to be prevailing among young adults and rulers and in national policy documents (Kåks, 2007; Svenson, 2006b; Rönnblom, 2014). Rönnblom pointed out that "the government's innovation strategy reproduces an urban prevalence" (p. 9).

Svensson $(2006 \mathrm{~b}, 2013)$ warned that this may stigmatize young people in rural areas concerning their self-esteem and self-understanding. In addition, it can mean a double or paradoxical approach to an individual's home county; he or she experiences a rich life, but the views in the community are negative. Young people's interpretations are based on "urban norm" and adults' expectations of living in big cities. Norm paradox of adults seems to be that young people are needed for the region's survival while the possibilities of a modern and youthful life exist elsewhere.

The lopsided power relationship has consequences when the country is regarded as problematic and flawed while the city represents modernity, growth, and success. It seems that rural residents need to develop many qualities such as flexibility and entrepreneurship (Svensson, 2014; Vallström \& Vallström, 2014). Mutual norms are needed for changes and trust, as well as national, regional, and local intellectual awareness that social capital needs to be renewed and match societal development. Some regions end up constantly at the bottom of the ranking lists, and different growth and prosperity indicators reinforce perceptions of "how things are," according to Vallström \& Vallström (2014). They argued that social capital should not be dichotomized. Education levels and creative occupations are internationally strongly related to regional development and income. What emerge as important influences today are creativity, technology, and tolerance (Florida et al., 2010). The so-called creative class seems to move more because of the job than the place (Niedomysl \& Hansen, 2010) and migration patterns of the class seem to be only marginally higher than those of other groups. These urban and rural norms are also addressed in international research concerning the perception that migration takes place of (in this example, in Canada and the US) the best and brightest young people, while denying the existence of those who remain and believing that they likely have the least to offer the community. Rural communities must provide possibilities, opportunities, and services for young people and see them as an investment in the future of society and not as a cost (Carr \& Kefalas, 2009). Although the importance of rural municipalities must be understood by youths, creating meeting places and participation in society also are described in international research (e.g., Cross \& Lauzon, 2015).

\subsection{Gender, Class, and Participation}

Structures seem to affect young people in different ways depending on gender and/or class in the current issue of whether to move or stay. Svensson (2011) showed that working-class children have a greater desire to remain. Young men focus more on future jobs and young women on family relations. However, for middle-class adolescents, migration becomes natural. Young men more often think of returning later, while middle-class young women move to find a "better life." Active participation of young people is of great importance for the development of a region. The social capital is a prerequisite for joint, mutual norms and networks, and it has the greatest significance for development, culture, and social environment (Dahlström, 1996). Not only research but also the national policy documents emphasize this. One example is the notion that young people being given the opportunity to participate actively in society is not only an issue of rights. Young people's experiences and perspectives are also an important resource for those who make decisions at all levels of society (Regeringen, 2011, p. 6).

Knowing that participation is important for young people's engagement and ultimately also for the democracy, Karlsson (1998) stated that participation in context - to be able to question what is happening and to participate in decisions - motivates individuals to seek knowledge and facts on various issues. It leads to greater accountability and increased self-confidence, self-awareness, and self-esteem. However, reality is not quite like this, according to Swedish research on regional youth. Svensson (2011) warned that young people's lack of interest can be/become a self-fulfilling prophecy, and she calls for strategies locally and regionally that can help young people have better impact opportunities. The actual conditions and expectations of the intended place of residence are a crucial determinant of whether young people remain. Social and cultural venues are prerequisites for rural sustainable development (Florida et al., 2010; Helve, 2003; Kåks, 2007).

\section{Purpose, Methodology, and Research Process}

Because there is a knowledge gap regarding young people's opinions, regional development, and school improvement, it is important to fill it in order to understand and influence the development of society. In this section, this approach and the research is described. 


\subsection{Purpose and Issues}

The aim is to find out how high school adolescents in the Mid Sweden Region think about present and future life in the municipality and how they think about the role school plays in their lives and future. Areas considered are whether they want to stay, move, and/or come back; desired development for the municipality; influencing factors; and motives in future personal choices. The research questions are as follows:

a) In the future, do young people think they will remain in the region, move, and/or come back later?"

b) How do young people think about different scenarios concerning home municipality and metropolitan living concerning a job and the future?

c) What/who directs the discussions about whether to remain or move?

d) Are there differences in this regard among different genders, regions, and age groups (high school and upper high school)?

\subsection{Sample, Methodology, Implementation, and Data-Collection Instruments}

The purpose of the survey was to find out young people's opinions concerning life and the future in the region. In order to examine their thoughts and attitudes, materials were gathered through a Web-based survey (see appendix 1) with open and closed questions. This study presents the quantitative findings. The empirical material upon which our analysis is based was obtained in the second year of the project period (spring 2014). Data were collected using a Web-based questionnaire that was administered by a link survey in the survey tool Netigate (www.netigate.se) to selected schools in the region. The survey was followed by a message explaining the study's purpose and that participation was voluntary and anonymous. The empirical basis for this study is based on responses from 1,484 students in the region.

The questionnaire (Note 3) consisted of questions in five main areas, the first of which was the background facts (age, gender, education level, region, and locality). Two other areas included rating scales and open issues with the following themes: staying or moving after high school and values about the school and the outside world. This analysis encompasses three main areas of inquiry. The survey was answered by 1,709 people but completed with useful responses by 1,484 people, including 740 young women, 717 young men, and 27 who did not specify their gender in the responses. All were students at high schools in the region. Before the questionnaire was sent out, it had been tested by six teachers and 12 students and examined in an academic forum.

The query structures for the Web-based survey were an operationalization of the theoretical concepts upon which the study was based, results of previous research, and aspects of school improvement and regional development that we considered relevant. The study followed the Swedish Research Council's rules and ethical recommendations for studies in social science research (http://www.codex.vr.se/texts/HSFR.pdf).

\subsection{Variables Describing the Sample}

The survey responses are described according to background variables including county, gender, type of school (high school and upper high school (Note 4)), and type of municipality (larger or smaller municipality). Municipalities that were counted as major were Östersund, Sundsvall, Örnsköldsvik, and Timrå. Other municipalities were counted as "minor." Another factor that may influence findings is a structural difference between the counties, namely the difference between counties in the number of municipalities and thus the size of the municipalities. It might be a more special choice to plan on living in a very small municipality than in a larger one. Therefore, this could be a partial explanation for the greater proportion of migration in Jämtlands than in Västernorrlands County. For a description of the replies and the distribution of these variables, see Table 1.

\subsection{Variables Related to Motives for Students' Plans}

The survey provided an opportunity to evaluate different scenarios, such as having a good job, "any job," or be unemployed in the municipality or the big city. The answers could determine how positively or negatively the young people valued working or studying, being able to remain in their home, and living in a big city. We used these responses to create factors and a quantitative measure of the attitude of these three aspects, as well as to reduce the number of variables and the complexity of the results.

The factors are then numeric and take values in the range of 0 to 12 . The names of the factors correspond to the three motives that emerge in the answers to the eight questions: Work or study is good; it is good to live in the big city; it is good to live in the home municipality (see Appendix 1).

\subsection{Variables for Context and Discussions}

Discussions and contexts in the analysis that played the role of positions consisted of the following variables: 
Teacher value; We young people value remaining in the region; We young people value big cities; Lessons about the importance of the region; Thinking to ourselves; Discussed the issue with peers and family. These variables were dichotomized.

\subsection{Analytical Methods}

The relationships between background variables and the dichotomized outcomes Planning to stay in the municipality and Planning to move from their home municipality were examined with logistic regression. Plan to stay was the event (event code $=1$ ) while plan to move was a complementary event (reference code $=0$ ). The data analysis of the motives' impact on plans to move was instead done with numeric outcomes. The three factors individually were examined with linear regression.

To study the influence of discussions and context of students' plans to move or stay (outcome), binary logistic regression was again used, and the outcome variable and explained variables were dichotomized. The analyses were done separately of Jämtland and Västernorrland. Gender was included as an additional explanatory variable. Influence of Counties, Gender and Lessons about the region's role were examined under the control of (taking into account) the variables We young people value stays, We young people value the big city better, Teacher value, Thinking to our self and Discussing with friends and family. The variables were dichotomized so code 1 means that the response was "Sometimes" or "Very often" and "Agree mostly" or "Agree completely." Code 0 means the answers "Not at all" or "Little" respective to "Disagree" or "Agree a little bit."

In the multiple linear regressions where the outcome variable is numeric, its average value between categories was compared in background variables with respect to the other explanatory variables in the regression analysis. The binary logistic regressions reported in the same way the effect of each variable under consideration of other explanatory variables. The outcome is the odds for a specific event. The odds of a student in a category giving a certain answer can then be compared with the odds for the outcome of a student in a different category. This is done by dividing over odds and reports the quotient, which is called the odds ratio.

Suppose that $40 \%$ of students answered "Planning to stay." Then the odds for that answer are $40 \div 60=0.67$, ie, the proportion of the response divided by the share of other responses. Suppose further that we want to compare the odds of the event "Planning to stay" between, for example, a category with $45 \%$ and $30 \%$ who gave that answer. First, the odds are $45 / 55$ and the other $30 / 70$ and the odds ratio is $45 / 55 \div 30 / 70 \approx 1.9$, which means that the odds of the event (questionnaire response) is 1.9 times the size of the first category of the other one. Furthermore, $45 \%$ "Planning to stay" against $35 \%$ gives 1.5 and $45 \%$ against $40 \%$ give 1.2 in odds ratio, which can provide help to the interpretation of the significance of these effects in terms of odds ratios.

\section{Results of the Data Analysis}

This section describes the study's results concerning the distribution of counties, gender, type of school, and school type. Furthermore, an account of young people's plans for moving, motives, influences, and context regarding moving plans.

\subsection{Description of the Distribution of Responses between Counties and the Background Variables}

Responses from major municipalities in Jämtlands County refer to Östersund, which is accounted for in $20 \%$ of the answers in the county. In Västernorrland Sundsvall, Örnsköldsvik and Timrå are considered to be major municipalities. As much as $96 \%$ of the respondents in this county came from a larger municipality. About three quarters of the responses from Västernorrland represented high schools (see Table 1).

Table 1. Respondents' distribution between counties and across Gender, Type of school, and Type of municipality

\begin{tabular}{lcc}
\hline & Jämtland: $\mathrm{n}=252$ & Västernorrland: $\mathrm{n}=1215$ \\
\hline Gender & & \\
Female & $58 \%$ & $49 \%$ \\
Men & $42 \%$ & $51 \%$ \\
Type of School & & \\
High school & $54 \%$ & $73 \%$ \\
Upper high school & $46 \%$ & $27 \%$ \\
Type of municipality & & \\
Larger & $20 \%$ & $96 \%$ \\
Smaller & $80 \%$ & $4 \%$ \\
\hline
\end{tabular}




\subsection{Young People's Thoughts about Staying in their Home Municipality or Moving}

In Jämtland, there was a significantly smaller proportion of students than in Västernorrland answering that they planned to continue living in their home municipality indefinitely or for a few years, $50 \%$ compared to $73 \%$ (Figure 2). A small part of this difference is explained by how the data collection was constructed. Firstly, there was a larger proportion of high school adolescents in the sample from Västernorrlands country, and there mostly young people from the larger municipalities there. In both counties, there were a larger proportion of the younger students who said they planned to stay. The difference was 15 percentage points. In Jämtland, there was almost no difference in the proportion of removable-prone adolescents between Östersund and the smaller municipalities, but it is still possible that the motives are such that the home municipality's size affects. In Västernorrland, there were in all cases a significantly smaller proportion who planned to stay in the municipality among those who belonged to the small municipalities. There is another factor that may influence a purely structural difference between the counties, namely the difference between counties in the number of municipalities and thus the size of the municipalities. One might describe it as a more extreme option, planning to live in a very small municipality than in a larger one. This could therefore be a partial explanation for why the proportion of migratory adolescents is more likely in Jämtland County than in Västernorrland.

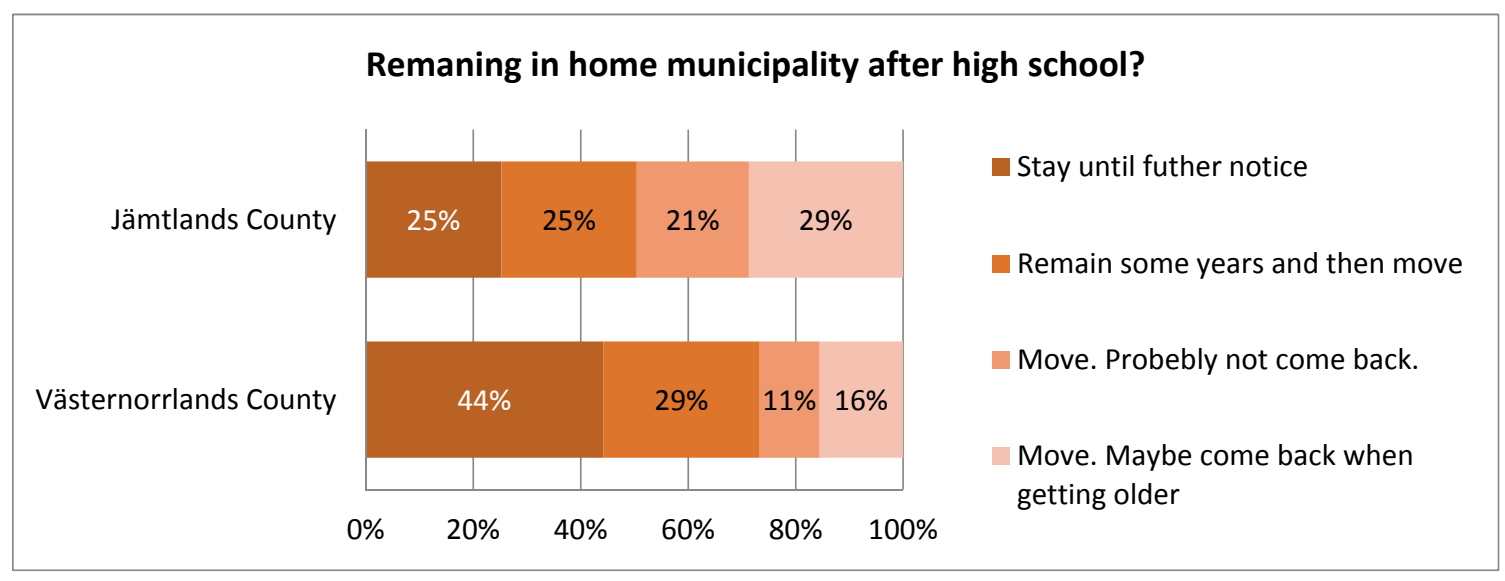

Figure 2. Young people's relocation plans by county

An analysis of the relationship between the explanatory variables Counties, Gender, Type of school, and Type of Municipality on one hand and Remaining (indefinitely or for a few years; dichotomized) is made with binary logistic regression (Table 2). The results show, for example, that the odds of a student from Västernorrlands County planning to stay in the municipality was 1.63 times as high as the corresponding odds of a student from Jämtlands County, under the control of Gender, Type of school, and Type of municipality. The corresponding odds of a male rather than a female, a high school student rather than an upper high school student, and a student living in a small community rather than in a large one, were all about 2 times as large-between 1.93 and 2.04 - under control of the other three variables in the analysis. The effects were all significant (p-values 0.000 to 0.044 ), but one should note that the effect of County was barely significant (p-value close to 0.05 ) when taking into account Gender, Type of school, and Type of municipality.

The analysis model used here has not been able to take into account the municipal structure in the counties, i.e., the size of the municipalities, which were commented on in the previous paragraph. We can only speculate what significance this has for the comparison between the counties. If we reason in accordance with the comment, the difference resulting from the counties should be somewhat overestimated in the analysis model. 
Table 2. Young people re-location plans and background data. Effects expressed as odds ratios

\begin{tabular}{lccccc}
\hline & B & S.E. & Wald & P-value & $\begin{array}{c}\text { Odds } \\
\text { ratios* }\end{array}$ \\
\hline $\begin{array}{l}\text { County (Västernorrland; reference Jämtland) } \\
\text { Gender (Male; reference Female) }\end{array}$ & 0.489 & 0.243 & 4.038 & 0.044 & 1.631 \\
$\begin{array}{l}\text { Type of school (High school; reference Upper } \\
\text { high school) }\end{array}$ & 0.712 & 0.136 & 27.244 & 0.000 & 2.038 \\
$\begin{array}{l}\text { Type of municipality (Larger; reference } \\
\text { Smaller) }\end{array}$ & 0.680 & 0.248 & 7.498 & 0.006 & 1.975 \\
Constant & -0.933 & 0.192 & 23.480 & 0.000 & \\
\hline
\end{tabular}

* For example, the odds ratio 1.932 for Gender means that the odds for young men to stay were about 1.9 times larger than for young women. Girl is the reference category.

\subsection{Summary of thoughts about remaining or moving}

We have seen that there are differences in the proportion of people who plan to live/remain in the municipality, especially a larger proportion of young men than women, a larger proportion of high school students than upper high schools students, and more adolescents in larger municipalities than in smaller villages planning to remain indefinitely or for a few years. The analysis also shows that there is a large portion that has such plans in Västernorrland than in Jämtland, but with a weaker effect. The analysis or the questionnaire also takes no account of the structural difference in the size of the municipality between the counties, which possibly could have contributed to the difference between counties in the answers to this question.

\subsection{Some Motives for Thoughts on Staying in the Home Municipality or Moving}

The survey provided an opportunity to evaluate different scenarios, such as having a good job, any job, or being unemployed in the municipality or the city. The answers could determine how positively or negatively the young people valued work or studying, for being able to remain in their home or to living in a big city. Regarding the setting, working or studying is good after upper high school, the average was almost 9 in the twelve-point scale, and the attitude that it is good to live in a big city averaged a little over 6.5. With regard to the attitude to continue living in their home county, it averaged just under 7 on the same scale.

The regression analysis showed that Type of municipality explained a significant portion $(\mathrm{p}$-value $=0.002)$ of the variation in measurement jobs and studies. Students from larger municipalities valued jobs and studies on average 0.5 points higher than others, when Gender, County, and Type of school were taken into account. Regarding the valuation of how good it is to live in the big city, only Gender had significant explanatory power ( $p$-value $=0.000$ ). Young women were an average of 0.5 points higher than young men on the scale, taking into account the County, Type of municipality, and Type of school. How good it is to live in the home municipality was valued significantly higher for young men than young women ( $\mathrm{p}$-value $=0.000$ ), and higher by students from smaller municipalities than from larger $(\mathrm{p}$-value $=0.000$ ). The effect size was 0.9 units for Gender and 1.0 units for Type of municipality.

\subsection{Summary of Motives for the Future}

By motives for plans to move from their home municipality, the adolescents said it would be good to live in a big city. The adolescents answered that perhaps it was "very good" to live in a big city if they have a job, "virtually any." The three motives we have chosen to score relate to the response to each of the sets of questions. Then, we investigated which of the background variables played a role in points of motive.

For "Jobs and Studies are good," the size of the municipality played a certain role. Adolescents from the larger municipalities have rated this higher on average than the rest, when account is taken of Gender, Type of school, and County. The motive "Good to stay in the big city" was a more attractive force for young women, i.e. they had higher average scores on this motive than young men, when taking into account Type of school, County, and Type of municipality. As for "Good to stay in the municipality," Gender and Type of municipality mattered. Young men had an average score higher than young women and students from small communities had higher scores than those from large, while taking into account Type of school and County.

The type of analysis we have done is, like all statistical analysis, interpreted with the knowledge that there is proportion or a mean in a category we are talking about, and there are always individual differences in reality. It is, for example, not that young women always focus on living in metropolises and young men do not, but that there may be more young women than men doing so. 


\subsection{The Context in Which the Question of Whether to Stay or Move is Discussed}

Several questions related to the question of whether to stay or move are discussed along with which circuit they are in. The questionnaire's formulation is about moving away or staying in the home municipality. Of the respondents, $70 \%$ of young women and $57 \%$ of young men answered that they "are talking to themselves" sometimes or often concerning moving or staying. As for whether they discussed this with friends or family, the responses were 54\% and $43 \%$, respectively, and in terms of the issue discussed during the lessons, $23 \%$ of young women and $28 \%$ of young men answered that it happens sometimes or often. The vast majority of young people, $91 \%$, think that they can influence where they will live and work, and only $24 \%$ responded that it is true mostly or entirely that teachers assess what is better or worse in this regard. But there are as many as $50 \%$ of high school students who say that they have lessons about the importance of the region. The corresponding upper high school rate is $23 \%$.

\subsection{Summary of Where and How the Question of Moving or Staying Is Discussed}

Less than half of the young men discussed the relocation issue with friends and family and little more than half are considering it themselves. Among young women, the proportions are larger. The difference is not very large, ten percentage points in both cases. About one student out of four feels that the issue is being discussed during the lessons, at least sometimes. Even more of the students, about half of high school youths and a quarter of upper high school youths respond that they have lessons about the importance of the region. This may be a compensation for those who rarely or never talk with family or peers about future positions.

\subsection{What Discussions and Contexts Affect Students' Plans?}

In the previous section, we saw that it was about twice the proportion of high school students who, compared to upper high school students who responded, say that they have lessons about the importance of the regions. Now we ask ourselves the question of whether such a difference matters to the proportion expressing plans to stay in the home municipality after high school. In the accounts for Jämtland (Table 3), we see that those who discuss the question of whether to stay or move with peers and family have the lowest odds ratio, 0.39 . Because it is a ratio less than 1 , this means that there is a lower proportion of them than of the others who plan to remain in their home municipality after upper high school. More precisely, this means that the odds of them planning to stay in their home municipality are 0.39 times as large for an individual in this category compared to one that answered that he or she rarely or never discuss the issue with colleagues or family. Those who value big cities highly also have an odds ratio well below zero, which is interpreted similarly. We also see that these results are significant (p-value 0.004 re-0.029, respectively).

The odds for plans to stay in the municipality are estimated to be 1.32 times higher for those who answered that they have lessons about the importance of the region. But the effect is not statistically significant, unlike the corresponding effect in Västernorrland (as we see in Table 3). The reason may well be that the proportion of upper high school students is lower in data from Jämtland, and that the base is less for Jämtland county than for Västernorrland in this study, which means that the statistical margin of error is larger.

Table 3. Adolescent moving plans and discussions. Jämtlands County

\begin{tabular}{|c|c|c|c|c|c|}
\hline & $\mathrm{B}$ & S.E. & Wald & P-value & Odds ratio* \\
\hline Teachers value & 0.316 & 0.380 & 0.693 & 0.405 & 1.372 \\
\hline We young people value remaining & 0.735 & 0.405 & 3.287 & 0.070 & 2.085 \\
\hline We young people value big cities & -0.711 & 0.325 & 4.786 & 0.029 & 0.491 \\
\hline $\begin{array}{l}\text { Lessons about importance of the } \\
\text { region }\end{array}$ & 0.278 & 0.323 & 0.738 & 0.390 & 1.320 \\
\hline Talking with myself & -0.310 & 0.341 & 0.827 & 0.363 & 0.734 \\
\hline $\begin{array}{l}\text { Discussions with friends and } \\
\text { family }\end{array}$ & -0.941 & 0.327 & 8.280 & 0.004 & 0.390 \\
\hline Constant & 0.845 & 0.393 & 4.616 & 0.032 & 2.327 \\
\hline
\end{tabular}

* See explanation text of Table 2.

The data for Västernorrland (Table 4) show the result that the odds ratios for each variable deviates from 1,000 in the same direction as in the Jämtland. Students who responded that they have lessons about the importance of the region have an odds ratio of 1.62 , i.e., the odds that they are planning to stay in the municipality are 1.62 times greater than those who answered this. Those who are talking with themselves or discussing with peers and family 
about the question to stay or move have about two-thirds as high odds ( 0.67 and 0.64$)$ for plans to stay than those who said they are considering with themselves or with peers and family. $P$-values are very low $(0.000<p<0.025)$ and show significant effects in all cases, except for the variable of Teacher value. There's also an odds ratio close to 1,000 , which means that the variable's effect was negligible or non-existent. The interpretations are otherwise equivalent to the previous, i.e., the results for each variable are calculated under the control of other variables in the model.

Table 4. Adolescent moving plans and discussions. Västernorrlands County

\begin{tabular}{lccccc}
\hline & B & S.E. & Wald & P-value & Odds ratio* \\
\hline Teachers value & 0.199 & 0.202 & 0.969 & 0.325 & 1.220 \\
We young people value remainin & 0.963 & 0.197 & 23.782 & 0.000 & 2.619 \\
$\begin{array}{l}\text { We young people value big cities } \\
\text { Lessons about importance of the }\end{array}$ & -0.886 & 0.168 & 27.696 & 0.000 & 0.412 \\
region & 0.481 & 0.167 & 8.324 & 0.004 & 1.617 \\
Talking with my self & -0.405 & 0.180 & 5.053 & 0.025 & 0.667 \\
$\begin{array}{l}\text { Discussions with friends and family } \\
\text { Constant }\end{array}$ & -0.447 & 0.166 & 7.197 & 0.007 & 0.640 \\
\hline
\end{tabular}

* See previous table.

In the following Table 5, we report the results of the regressions with the same variables as above, but with gender as an additional explanatory variable. The effects (odds ratios) of the explanatory variables in addition to gender are basically the same as the processing that does not include the variable. This means that there is not in any significant interaction between Gender and other variables in the model. We see that Gender in itself has a significant $(\mathrm{p}=0.015)$ effect, which means that the young women odds to stay in the municipality are $71 \%$ of the young men's' odds. The only variable with a significant effect is Teacher value $(p=0.344)$.

Table 5. Adolescents fled plans and discussions and gender

\begin{tabular}{lcccccc}
\hline & B & S.E. & Wald & P-value & Odds ratio $^{1}$ & $\begin{array}{c}\text { Odds ratio }^{2} \\
\text { exkl. Gender }^{2}\end{array}$ \\
\hline Teachers value & 0.167 & 0.177 & 0.896 & 0.344 & 1.182 & 1.24 \\
We young people value remaining & 0.949 & 0.175 & 29.279 & 0.000 & 2.584 & 2.68 \\
We young people value big cities & -0.811 & 0.148 & 30.091 & 0.000 & 0.445 & 0.42 \\
Lessons about importance of region & 0.481 & 0.146 & 10.809 & 0.001 & 1.618 & 1.60 \\
Talking with myself & -0.523 & 0.148 & 12.516 & 0.000 & 0.593 & 0.56 \\
Discussions with friends and family & -0.368 & 0.158 & 5.405 & 0.020 & 0.692 & 0.69 \\
Gender & -0.338 & 0.138 & 5.951 & 0.015 & 0.714 & \\
Constant & 1.702 & 0.236 & 51.867 & 0.000 & 5.483 & 4.157 \\
\hline
\end{tabular}

${ }^{1}$ See previous table

${ }^{2}$ The effects of processing with no breakdown by County or Gender

\subsection{Summary of Influence through Discussions and Context}

We have seen that lessons about regional perspectives are reported twice as often from high school students as upper high school students. These lessons seem to have some effect on how young people formulate their plans for the future. The effect is quite strongly positive for plans to stay in the municipality and the statistical significance of the data from Västernorrland. In Jämtland, the effect seems to be smaller and not significant, although the direction of the endpoint is the same as in the Västernorrland part of the data. When the dataset from both counties were used in the analysis and consideration was given to the variables that were statistically associated with the variable of future plans, the lessons of the region's importance have a significant positive impact concerning plans to stay in home municipalities. The effect is significant with a p-value as low as 0.001 .

Other significant effects were discussed with peers and family, which had a negative effect in both Counties and Thinking to themselves, which showed a significant negative effect in Västernorrland, but not in Jämtland. By negative, we mean that there were lower proportions of youths with plans to stay in the municipality among those 
who would frequently think with themselves or discuss with friends and family.

\section{Discussion and Conclusions}

The last section first provides a summary and results of the study, then follows implications regarding urban/rural norms, education, and regional policy and pedagogy, as well as a methodological discussion and, finally, proposals for further studies.

\subsection{Summary}

The background to this study is the brain drain of educated people and the relatively low school results from the Mid Sweden Region. The context is youth migration patterns and rural regional perspective on urban / rural norms, gender, class, and participation. Previous research has demonstrated a knowledge gap regarding youth, regional development, and school improvement (Boström, 2015a, 2015b; Möller, 2011). Research from the Mid Sweden Region has shown that a majority of young people, especially young women studying academic pro-grams, plan to move from their home municipality after high school. Especially young women seem to have more, or different, ranges of leisure compared to young men (Dalin et al., 2013; Kostela et al., 2013). In Västernorrland, the results show that students believe that school, teaching, and teachers should be key priority areas (Dalin et al., 2013). Even educational level and transition to higher education is lower in the Mid Sweden Region compared with the country at large (UHÄ, 2014; Lindh, 2015). Previous research has shown that young people's tendencies to migrate are all about providing jobs, education, and experiences, but also on basic urban/ rural norms in society. These are based on a dichotomization of city and country, where the metropolitan norm is prevalent. You could describe this as a kind of power dynamics, where one feature is valued higher. This power structure affects the development opportunities that are attributed to respective forms of society, which in turn have implications at several levels. Gender, class, and participation are structures that also affect the moving and future plans of young people in rural areas. The Agriculture Board (2013) encourages critical thinking about norms concerning city and country.

The purpose of this study is to find out more about how young people in the Mid Sweden Region are thinking when it comes to the future. Research questions focus on adolescents' thoughts about staying or moving, about the future in urban or rural areas, influences on future choices, and possible differences between gender, region, and age groups. The results are based on about 1,500 survey responses from young people in the Mid Sweden Region, which are processed with a quantitative approach.

We note that a large proportion of youth in Jämtlands County (about 50\%) say they think about moving and want to move, while the proportion in Västernorrlands County are lower (about 37\%). The differences may be because Västernorrlands County is on the coast and Jämtlands County is situated in the mountains in the hinterland. It is obvious that young women more so than young men want to move, which is consistent with previous research (see Dalin et al., 2013; Kostela et al., 2013). Furthermore, one can see that the high school adolescents, compared with upper high school adolescents and young people from smaller municipalities compared to the larger ones, plan to move. This difference may be due to age; that is, when studying in upper high school future choices will be closer. The results regarding size of municipality may, inter alia, relate to young people's motives to stay or move. Jobs and education play a major role for them, and it is natural that the supply is smaller in the small municipalities. Another clear motive to move to the big city is experiencing its attraction-force. In this context, this may be due to urban standards and its prevalence (cf. Kåks, 2007; Vallström \& Vallström, 2014).

The contexts in which young people are thinking about relocation plans the most are "by them self" and "with peers." About a quarter of young people feel that the issue should be discussed during lessons, and a much greater extent do so in high school compared to upper high school. The study shows that lessons about the importance of the region have a positive, significant effect on their plans to remain in their home municipality. And the opposite; those who thought with themselves or with peers, responded that they were more likely to move.

To conclude, the study largely confirms previous research, which is that for young people moving from rural areas, jobs and education are important motives and young women are the most prone to move. What appears to be completely new knowledge is that education in schools about the region is important for young people's choice to remain. The school's importance for young people in the region has been confirmed in previous research (Dalin et al., 2013), but not as an influencing factor on young people's choice to remain. This should be updated for both local politics regionally and nationally, but more importantly in school discourse. When the school plays a role in students' thinking and future choices, larger formation efforts on regional development are of great value for norms about regional political standpoints.

\subsection{Implications}

As previous research has shown for the average person, sparsely populated / rural areas lose population, especially 
young people and young women motivated to study, in favor of cities. Considering the existing urban prevalence (cf. Kåks, 2007; Rönnblom, 2014), we believe that this is a structure and power dynamic that should be addressed in many contexts and forum not least in schools. The Board of Agriculture (2013) calls for awareness and critical thinking on the matter, which are highly relevant. To highlight values on a collective level for living and working in rural areas could change this current polarization. Values of rural life for young people should be made clear. This would partly change the perception of life qualities in the home district for those who already live there, but also attract young people to move to rural areas. In this context, family, school, local community, local businesses, and regional policy are important roles and interactions for young people to feel a positive identity with their homeland, their social origin, their gender, and their family. Norm paradoxes for the region's survival and the importance of young people's chances for "better" youthful experiences in the big city that emerge in earlier research (e.g., Svensson, 2011), are linked to this.

New norms for young people who choose to remain are also needed. These young people should not feel like "losers" (cf. Svensson, 2014), but as just as important of a social group as the rest of society (politicians, adults, school, etc.) that upgrades possibilities for participation and creates meeting places (cf. Carr and Kefalas, 2015). This is about mutual norms and trust (cf. Vallström \& Vallström, 2014). There is not enough of a change in norms. Regional policy initiatives in the form of relocation of jobs to rural areas are more important than ever. Above all, young women should have opportunities to study in rural areas and stimulate the economy with needed jobs.

The education policy implications of this study are that higher education should be made possible for students in rural areas. If they can get the opportunity to live and study in their home municipality, there is a greater possibility that they will remain. In today's digital society, perhaps alternative, remote work is a possible area of development, so that people are better able to work from home.

The educational implications of the study are that schools play a role in young people's critical thinking. Teaching about rural areas and cities, where both standards are presented as equal, sets the stage and plays a role of young people's own standards and future choices. Several school subjects and themes can cooperate in the training of urban and rural areas, such as social studies, natural knowledge, and language. But if education starts, it can be important to examine which training is available and how it can be developed / improved.

\subsection{Methodological Discussion}

As stated previously, we do not have data collection balanced to streamline some comparisons. Among the responses from Västernorrlands County, there were a significantly higher proportion of responses from students in high school than in Jämtland County and a large majority of the responses that represented Västernorrland came from larger municipalities, whereas most of the responses came from small municipalities. Differences between the counties cannot be interpreted as the effects of differences in policies. They could be the result of trends in differences in attitudes between students in larger and smaller municipalities as well as between students in high school and upper high school. Using multiple regression analysis, i.e., with several explanatory variables simultaneously in the model, we have, as far as possible, kept apart the effects of the different background variables from each other.

\subsection{Further Research}

To go deeper into young people's choices from the Mid Sweden Region is an important area of research, and nationally there are several areas grappling with the same problem. This will be done with the qualitative data material in this research project. Another possible research area is to make experimental study lessons on the content and significance of future re-locations of young people. Also, studies on the type of teaching that matters, and which topics of regional issues are addressed and how, are a possible area for future research.

\section{References}

Boström, L. (2015a). Regional educational development research in Sweden: A literature review of research over half a century. Journal of Studies in Education, 5(2), 1-31. https://doi.org/10.5296/jse.v5i2.7197

Boström, L. (2015b). Regional Educational Development Research and School Improvement: A Systematic Literature Review of Research. International Journal of Learning, Teaching and Educational Research, 11(1), 200-211. https://doi.org/10.11114/jets.v4i2.1114

Boverket (2012). Vision för Sverige 2025 [Vision for Sweden]. Retrieved from http://www.boverket.se/ globalassets/publikationer/dokument/2012/vision-for-sverige-2025.pdfwww.boverket.se/

Carr, P., \& Kefalas, M. (2009) Hollowing Out the Middle: The Rural Brain Drain and What It Means for America. Library Journal, 134(18), 84 https://doi.org/10.5860/choice.47-4732 
Cross, H., \& Lauzon, A. (2015). Fostering Rural Youth Wellbeing through Afterschool Programs: The Case of Fusion Youth and Technology Center Ingersoll, Ontario. Journal of Rural and Community Development, 10(1), 128-153. https://doi.org/10.4018/978-1-4666-9577-1.ch017

Dahlström, M. (1996). Young women in a male periphery_Experiences from the Scandinavian north. Journal of Rural Studies, 12(3), 259-271 https://doi.org/10.1016/0743-0167(96)00018-6

Dalin, R., Bostedt G., \& Blusi, M. (2013). Ungdomar i Västernorrland - åsikter och attityder [Young people in Västernorrland - opinions and attitudes]. Rapport 2013:12 FOU Västernorrland.

Florida, R., Mellander, C., \& Stolarick, K. (2010). Talent, technology and tolerance in Canadian regional development. The Canadian Geographer, 54(3), 277-304. https://doi.org/10.1111/j.1541-0064.2009.00293.x

Hammarström, M. (2004). En högskola för alla? Vägen dit för glesbygdsungdomar [A university for all? The way there for the rural youth]. Report. Jönköping. Högskolan för lärande och kommunikation.

Helve, H. (2003). Ung i utkant - aktuell forskning om glesbygdsungdomar i Norden [Young on the fringes: current research on rural youth in the Nordic region]. Nordiska ministerrådet 2003.

Jordbruksverket. (2013). Så här definierar vi landsbygd [How we define rural areas]. Retrieved from http://www.jordbruksverket.se/etjanster/etjanster/landsbygdsutveckling/alltomlandet/sahardefinierarvilands bygd.4.362991bd13f31 cadcc256b.html

Kåks, H. (2007). Mellan erfarenhet och förväntan: Betydelser av att bli vuxen i ungdomars livsberättelser [Between experience and expectation: Meanings of becoming an adult in young people's life stories]. Linköping University; Linköping Studies in Arts and Science, Avhandlingar vid Tema Kultur och samhälle, 2007.

Karlsson, E. (1998). Ungdomars självstyre [Young people's autonomy] (in) SOU 1998:101. Det unga medborgarskapet - dokumentation från ett seminarium. Demokratiutredningen skrift $\mathrm{nr}$ 5. Stockholm: Fritzes.

Kostela, J., Jansson, J., \& Möller, P. (2013). LUPP-enkät Jämtland 2012 Enkätundersökning av ungdomar i åk 8 på högstadiet och åk 2 på gymnasiet [LUPP survey Jämtland 2012 Survey of young people in grade 8 at the high school and year 2 of upper high school]. Falun; Högskolan Dalarna.

Lindh, H. (2015). Sökande och studenter - frän regionen till Mittuniversitetet [Applicants and students - from the region to Mid Sweden University]. Intern rapport.

Möller, P. (2011). Inledning. [Introduction]. In P. Möller (Ed.), Vem bygger landet? Om unga och vuxna I den regionala utvecklingen (pp. 9-14). Vilnius: Gidlunds Förlag.

Myndigheten för tillväxtpolitiska utvärderingar och analyser. (2011). Pågående landsbygdsforskning - en översikt [On going rural research - an overview]. Working paper/PM. 2011:03.

Niedomysl, T., \& Hansen, H.K. (2010). What matters more for the decision to move: Job versus amenities. Environment and Planning, 42, 1636-1649. https://doi.org/10.1068/a42432

Nilsson, B., \& Lundgren, A. S. (2015). Logics of rurality: Political rhetoric about the Swedish North. Journal of Rural Studies, 37, 85-95 https://doi.org/10.1016/j.jrurstud.2014.11.012

Regeringen. (2011). SOU 1998:101 Det unga medborgarskapet - dokumentation från ett seminarium [The young citizenship - Documentation from a seminar]. Demokratiutredningen skrift 5. Stockholm: Fritzes. Hämtad. Retrieved from https://www.regeringen.se/sb/d/2479/a/117782 2011-02-14

Rönnblom, M. (2014). Ett urbant tolkningsföreträde? En studie av hur landsbygd skapas i nationell policy [An urban prevail? A study of how rural is created in the national policy].Umeå Centrum för genusstudier; Umeå Universiet。

Sayer, A. (1992). Method in social science: a realist approach. London:Routledge.

Skolverket. (2014). SALSA/SIRIS. Retrieved from http://www.skolverket.se/statistik-och-utvardering/statistik-idatabaser

Statistiska Centralbyrån. (2014). Utflyttande högskoleutbildade från Jämtlands och Västernorrlands län [Out-migration of college-educated in Jämtlands and Västernorrlands counties compared to the whole of Sweden]. Retrieved from http://www.scb.se/sv_/Hitta-statistik/

Svensson, L. (2006). Här får du inte vara med om du inte flyttar härifrån: Om ungdom och regional utveckling [Here you will not be counted on if you are not moving from here: Youth and regional development]. Locus, 
2006(3), 21-34.

Svensson, L. (2006). Vinna och försvinna? Drivkrafter bakom ungdomars utflyttning från mindre orter [Winning and disappear? Levers of youth out-migration from small villages]. Linköping: Linköping Studies in Education and Psychology.

Svensson, L. (2011). Ungas bristande intresse för lokal utveckling - en självuppfyllande profetia? [Young people's lack of interest in local development - a self-fulfilling prophecy?]. In P. Möller (Ed.), Vem bygger landet? Vilnius: Gidlunds förlag.

Svensson, 1. (2013). We don't want you to join us if you don't leave us! In Fraser of Allander Institute. Economic commentary. Special Issue No 4. Economic and social aspects of Peripheral regions (pp. 45-51).

Svensson, L. (2014). Nu styr vi upp stan [Now we head up the town]. In M. Vallström (Ed.), När verkligheten inte stämmer med kartan. Lokala förutsättningar för hållbar utveckling. Lund: Nordic Academic Press.

Tillväxtverket. (2014). Fakta och statistik för regioner och län [Facts and statistics for regions and counties]. Retrieved from http://www.tillvaxtverket.se/huvudmeny/faktaochstatistik/regioner.4.2fb8c83014597db7ce 9777c8.html

UKÄ. (2014). Stora skillnader i rekrytering av unga till högre utbildning [Large differences in the recruitment of young people into higher education]. Retrieved from http://www.uka.se/arkiv/statistiskaanalyser/ storaregionalaskillnaderirekryteringavungatillhogreutbildning.5.418d928c147afe46a08488.html

Vallström, M., \& Vallström, M. (2014). Hållbar utveckling på kartan och i verkligheten [Sustainable development on the map and in reality]. In M. Vallström (Ed.), När verkligheten inte stämmer med kartan. Lokala förutsättningar för hållbar utveckling. Lund: Nordic Academic Press.

Westholm, E. (2008). Vad menas egentligen med landsbygd?[What is meant by rural?]. In B. Johansson (Ed.), Ska hela Sverige leva? Stockholm: Formas Fokuserar.

Westholm, E., \& Waldenström, C. (2008). Kunskap om landsbygden. Dags för en ny agenda! [Knowledge of the countryside. Time for a new agenda!]. Institutet för framtidsstudier, 2008(1).

\section{Notes}

Note 1. In this study, the Mid Sweden Region is defined as Jämtlands och Västernorrlands counties.

Note 2. The two concepts of sparsely populated and rural areas are described in 2.1. In the following text, we use the concept "rural" in the study because of the study's eight municipalities are defined as rural countryside, three rural, and three urban areas

Note 3. Some of the questions that have been used in his research on young people's opinions about rural areas were constructed by PhD Lotta Svensson (Svensson, 2006b, 2013, 2014).

Note 4. In Sweden, we distinguish high school, where 13-16 year olds are found, from upper high school, where 17-19 year olds receive education.

\section{Appendix 1}

Excerpts from the Web survey

2. Staying or moving after upper high school?

a) Do you plan to remain in your home municipality after upper high school?

$\square$ Yes, I intend to remain in my home municipality until further notice.

$\square$ Yes, I intend to remain in my home municipality for a time, but move within a few years.

$\square$ I'm thinking of moving after high school and I will probably not move back.

$\square$ I intend to move right after high school, and perhaps move back when I get older 
c) How do you think the following would be?

\begin{tabular}{|l|l|l|l|l|}
\hline & Very good & Fairly good & Fairly bad & Very bad \\
\hline To study and stay in my home municipality? & & & & \\
\hline To study and stay in my home municipality? & & & & \\
\hline To study and stay in my home municipality? & & & & \\
\hline Having a good job in my home municipality? & & & & \\
\hline $\begin{array}{l}\text { Being unemployed and living in my home } \\
\text { municipality? }\end{array}$ & & & & \\
\hline To study and live in a big city? & & & & \\
\hline Having a job, any, and staying in a metropolis? & & & & \\
\hline Have a good job and living in a big city? & & & & \\
\hline Being unemployed and living in a big city? & & & & \\
\hline
\end{tabular}

d) Discussions about staying or moving

\begin{tabular}{|l|l|l|l|l|}
\hline & Very often & Sometimes & A little bit & Not at all \\
\hline $\begin{array}{l}\text { To what extent are staying or moving in the region } \\
\text { discussed in school during lessons? }\end{array}$ & & & & \\
\hline $\begin{array}{l}\text { To what extent are staying in or moving from the } \\
\text { region discussed with peers and family? }\end{array}$ & & & & \\
\hline $\begin{array}{l}\text { To what extent are staying in or moving from the } \\
\text { region discussed with peers and family? }\end{array}$ & & & & \\
\hline
\end{tabular}

4. Values. Take a position on these statements

\begin{tabular}{|l|l|l|l|l|}
\hline & $\begin{array}{l}\text { Agree } \\
\text { completely }\end{array}$ & Agree mostly & Agree a little bit & Disagree \\
\hline $\begin{array}{l}\text { We have lessons dealing with the region's } \\
\text { importance. }\end{array}$ & & & & \\
\hline $\begin{array}{l}\text { My school grades are important and play a role if I } \\
\text { stay or move. }\end{array}$ & & & & \\
\hline The politicians are listening to our wishes. & & & & \\
\hline We young people value moving to a big city more. & & & & \\
\hline $\begin{array}{l}\text { We young people value remaining in our home } \\
\text { municipality more. }\end{array}$ & & & & \\
\hline $\begin{array}{l}\text { Teachers educate on what is better and worse when } \\
\text { it comes to staying or moving. }\end{array}$ & & & & \\
\hline
\end{tabular}

\section{Copyrights}

Copyright for this article is retained by the author(s), with first publication rights granted to the journal.

This is an open-access article distributed under the terms and conditions of the Creative Commons Attribution license (http://creativecommons.org/licenses/by/4.0/). 